
$\$$ Research Square
Preprints are preliminary reports that have not undergone peer review.
They should not be considered conclusive, used to inform clinical practice, or referenced by the media as validated information.

\title{
Lipid Productivity and Biosynthesis Genes Response of Indigenous Chlorella sp. T4 Strain under Different Nitrogen and Phosphorus Load
}

S'fiso Thuthukani Gumbi

University of KwaZulu-Natal - Westville Campus

Ajit Kumar

University of KwaZulu-Natal - Westville Campus

Ademola Olufolahan Olaniran ( $\nabla$ olanirana@ukzn.ac.za )

University of KwaZulu-Natal - Westville Campus https://orcid.org/0000-0002-0586-0558

\section{Research Article}

Keywords: Chlorella sp. T4, Gene expression, Fatty acid, Nutrients, Lipid accumulation, Physiological response.

Posted Date: November 15th, 2021

DOI: https://doi.org/10.21203/rs.3.rs-1070807/v1

License: (a) (1) This work is licensed under a Creative Commons Attribution 4.0 International License. Read Full License 


\section{Abstract}

Microalgae can synthesize and accumulate high neutral lipids upon exposure to abiotic stress such as nutrient starvation or limitation. In this study, indigenous microalgae Chlorella sp. T4 was cultivated in nitrogen and phosphorus under both limiting and replete conditions. Growth, lipid yield, fatty acid profiles and biosynthetic gene expression levels were determined to ascertain cell's response under these conditions. An impaired cell growth was observed under nitrogen limiting condition, evident by the lowest biomass yield $\left(0.58 \pm 0.03 \mathrm{~g} \mathrm{~L}^{-1}\right)$ as revealed by low quantum efficiency of photosystem II (Fv/Fm) value and chlorophyll a content. An increase in lipid content yield was observed under nitrogen and phosphorus limiting conditions as compared to the control. Nutrient limiting conditions produced fatty acid methyl ester that is suitable for biodiesel production compared to the control (BG-11). Gene expression analysis using real time q-PCR for photosynthesis ( $r b c L)$ and lipid biosynthesis ( $a c c D, K A S-1, \omega-6$ FAD, $\omega-3$ FAD) genes revealed different expression levels under both limiting and replete conditions. Under nutrient limiting conditions, increase in the expression of $a c c D, K A S-1, \omega-6 F A D$ and $\omega-3$ FAD genes was observed, whereas a decrease in $r b c L$ gene expression level was noted. A significant correlation could be drawn between the expression levels of the biosynthetic genes and growth rate, biomass yield, physiological response, lipid yield and fatty acid composition. These results provide an insight into the physiological response and gene expression level under different nutrient levels, which could be harnessed for future genetic engineering of Chlorella sp. T4 for improved lipid production.

\section{Introduction}

The demand for biodiesel, as a replacement for the conventional fossil fuel, is growing worldwide in recent years [1]. Microalgae have been a favourable feedstock for biodiesel production due to its fast growth rate, high lipid yield, suitable fatty acid composition and adaptability to a wide range of climatic environment [2, 3], but high production cost at commercial scale is still a major drawback [4]. Microalgae tend to accumulate energy storage material in form of lipids and starch under stress conditions, when the cell growth reaches the stationary phase [5]. It has been shown that optimization of microalgae culture condition can result into high lipid productivities in microalgal biomass. Manipulation of several key intrinsic and extrinsic factors such as nutrient stress, light intensity, temperature, and carbon source triggers lipid accumulation pathway [6-8]. Nutrient deprivation is often used by many researchers to improve overall microalgal lipid productivity, due to it's low cost and easy application during the cultivation process [9]. This approach causes decrease in photosynthetic rates, and compromises biomass accumulation, while resulting in enhanced overall lipid storage in form of triacylglycerol $[10,11]$. Nitrogen $(\mathrm{N})$ is regarded as important micro-nutrient for microalgal growth, as it is associated with protein synthesis and cell division [11], whereas phosphorus $(P)$ contributes to various metabolic processes such as signaling pathways, energy generation and photosynthesis.

Most studies have been focused on obtaining high lipid productivity yield under nutrient-stress conditions, without a proper understanding of the effect of these conditions on the microalgae photosynthesis activity, physiological response, and gene expression levels under these conditions [12, 
13]. The understanding of microalgal response at the molecular level is limiting to few species, such as Chlamydomonas reinhardtti, Thalassiosira psuedonana and Dunaliella salina [14]. The microalgae under study, Chlorella sp. T4 strain, isolated in our laboratory, have demonstrated huge potential to accumulate large amount of fatty acid that can be used for biodiesel production [15]. In this study, different concentrations of $\mathrm{N}$ and $\mathrm{P}$ were applied to trigger hyper lipid accumulation in this indigenous microalga. Furthermore, the physiological response of the microalgae under different nutrient conditions and expression levels of five key fatty acid biosynthetic genes ( $r b c L$, accD, KAS-1, $\omega-6 F A D$ and $\omega-3 F A D$ ) were investigated. The $r b c L$ gene encodes the catalytic large subunit of the enzyme RuBisCO (ribulose 1.5bisphosphate carboxylase/oxygenase) which is responsible for carbon fixation, catalyzing the first step in the Calvin cycle [14]. Previous study reported a decrease in $r b c L$ gene expression under $\mathrm{N}$ and $\mathrm{P}$ deficient conditions in Chlorella sorokiniana [3]. accD encodes for acetyl-coenzyme A carboxylase carboxyl transferase subunit beta which is responsible for fatty acid biosynthesis, and catalyses the conversion of acetyl-CoA to malonyl-CoA during the lipid biosynthesis [6]. An increase in $a c c D$ expression under nutrient deficient conditions has been reported in Chlorella pyrenoidosa [16]. The expression levels of three fatty acid biosynthetic genes; KAS-1, $\omega-6 F A D$ and $\omega-3$ FAD in relation to fatty acid yield under different $\mathrm{N}$ and $\mathrm{P}$ concentrations have been investigated. The $K A S-1$ gene encodes for ketoacyl-ACP synthase-1 responsible for the addition of malonyl-CoA to elongate 4-carbon fatty acid to 6-, 12- and 16 carbon fatty acid chains, for the production of palmitic and stearic acid. Furthermore, $\omega-6$ FAD gene which encodes for omega- 6 desaturase responsible for catalyzing the conversion of oleic acid into linoleic acid, while $\omega-3$ FAD gene code for omega-3 desaturase which is responsible for the conversion of $\omega-6$ fatty acid into $\omega-3$ fatty acid [17-19]. Therefore, the aim of the present study was to design suitable cultivation conditions for high lipid accumulation that can be used for biodiesel production. To understand the expression of key functional genes ( $r b c L, a c c D, K A S-1, \omega-6 F A D$ and $\omega-3 F A D)$ by varying $\mathrm{N}$ and $\mathrm{P}$ concentration in the growth medium.

\section{Materials And Methods}

\subsection{Algal strain and seed preparation}

The microalgal strain Chlorella sp. T4 used in this study was isolated from freshwater body in KwaZuluNatal, South Africa [15]. The strain was preserved in BG-11 medium which is composed of $\left(\mathrm{g} \mathrm{L}^{-1}\right)$ : $\mathrm{NaNO}_{3}, 1.5 ; \mathrm{K}_{2} \mathrm{HPO}_{4}, 0.04 ; \mathrm{MgSO}_{4} .7 \mathrm{H}_{2} \mathrm{O}, 0.75 ; \mathrm{CaCl}_{2} \star 2 \mathrm{H}_{2} \mathrm{O}, 0.036$; citric acid, 0.006 ; ferric ammonium citrate, 0.006; EDTA, 0.001; $\mathrm{Na}_{2} \mathrm{CO}_{3}, 0.02$ and $1 \mathrm{~mL}$ of micronutrient or trace metal solution containing (g

$\mathrm{L}^{-1}$ ): $\mathrm{H}_{3} \mathrm{BO}_{3}, 2.86 ; \mathrm{MnCl}_{2} * 4 \mathrm{H}_{2} \mathrm{O}, 1.81 ; \mathrm{ZnSO}_{4} * 7 \mathrm{H}_{2} \mathrm{O}, 0.22 ; \mathrm{NaMoO}_{4} .5 \mathrm{H}_{2} \mathrm{O}, 0.079 ; \mathrm{Co}\left(\mathrm{NO}_{3}\right)_{2}{ }^{*} 6 \mathrm{H}_{2} \mathrm{O}, 0.04$. The medium was adjusted to a $\mathrm{pH}$ of 7 and sterilized in an autoclave at $121^{\circ} \mathrm{C}$ for $15 \mathrm{~min}$.

The culture $(10 \% \mathrm{v} / \mathrm{v})$ was inoculated in $500 \mathrm{~mL}$ conical Erlenmeyer flaks containing $200 \mathrm{~mL}$ of BG-11 medium. An aliquot of tetracycline $\left(0.5 \mu \mathrm{mL}^{-1}\right)$ was added to the growth medium to prevent any bacterial contamination in the microalgal samples. The culture was incubated at $25^{\circ} \mathrm{C}$ under cool white fluorescent illumination of $200 \mu \mathrm{mol} \mathrm{m} \mathrm{m}^{-2} \mathrm{~s}^{-1}$ with a photoperiod of $12 \mathrm{~h}$ : $12 \mathrm{~h}$, light: dark cycle under 
ambient $\mathrm{CO}_{2}$. Similar cultivation conditions were maintained for all the subsequent experiments. The cultures were hand-shaken two to three times daily to avoid settling and sticking of the culture onto the bottom of the flask.

\subsection{Experimental design and physiological parameters analysis}

To find the best nitrogen $(\mathrm{N})$ and phosphorus $(\mathrm{P})$ concentration for high lipid productivity yield, Chlorella sp. T4 was cultivated in BG-11 medium containing sodium nitrates $\left(0.75\right.$ and $\left.2.25 \mathrm{~g} \mathrm{~L}^{-1}\right)$ and dipotassium-ortho-phosphate $\left(0.02\right.$ and $\left.0.06 \mathrm{~g} \mathrm{~L}^{-1}\right)$. These nutrient concentrations were selected based on the lipid productivity yield obtained from the preliminary study conducted by growing the microalgae strain on BG-11 containing different concentrations of $\mathrm{N}\left(0,0.35,0.75,2.25 \mathrm{~g} \mathrm{~L}^{-1}\right)$ and $\mathrm{P}(0,0.02,0.04$, $\left.0.06 \mathrm{~g} \mathrm{~L}^{-1}\right)$. Optimization was conducted with one factor at a time, and other individual media composition kept constant as in BG-11 to assess the individual effect of the culture treatment on Chlorella sp. T4. In addition, control experiment was conducted using BG-11 medium with normal concentration of sodium nitrates $\left(1.5 \mathrm{~g} \mathrm{~L}^{-1}\right)$ and di-potassium-ortho-phosphate $\left(0.04 \mathrm{~g} \mathrm{~L}^{-1}\right)$ that is known to support microalgae growth. The algal cell was standardized to the optical density of 0.05 at $680 \mathrm{~nm}$. The cells were harvested by centrifugation at $5000 \mathrm{rpm}$ for $10 \mathrm{~min}$, washed with distilled water, and resuspended into appropriate medium containing different concentrations of sodium nitrate and di-

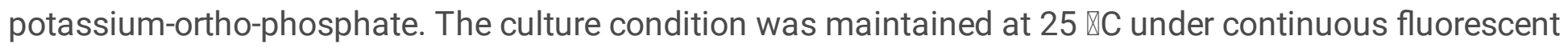
light with light intensity of approximately $100 \mu \mathrm{mol} \mathrm{m} \mathrm{m}^{-2} \mathrm{~s}^{-1}$, and the flasks were hand shaken 2 to 3 times a day.

The Chlorophyll a content of Chlorella sp. T4 was measured as described previously [20]. The physiological and photosynthesis efficiency of the microalgal cells were studied as described previously [21]. The maximum quantum efficiency of Photosystem II (PS II) was calculated using the equation: $F_{v} / F_{m}=\left(F_{m}-F_{0}\right) / F_{m}$ as previously described [21], Where $F_{m}, F_{o}$, and $F v$ represents the maximum, minimum and variable fluorescence, respectively.

\subsection{Measurement of cell growth, biomass concentration, lipid yield and fatty acid content}

Cell growth determination, biomass concentration measurement, and algal lipids extraction and weight determination were carried out as described previously [15]. The harvesting was done by centrifugation at $5000 \mathrm{rpm}$ for $10 \mathrm{~min}$. The fatty acid content were quantified as described previously [15] while the biodiesel properties were estimated using the web version of the Biodiesel Analyzer 2.2 [22].

\subsection{Gene expression analysis}

The expression levels of five key fatty acid biosynthetic genes ( $r b c L, a c c D, K A S-1, \omega-6 F A D$ and $\omega-3 F A D)$ were determined in samples collected at the early log phase (day 7), late log phase (day 14) and stationary phase (day 21) of growth in the different nutritional growth conditions. The total RNA was 
extracted from $\approx 100 \mathrm{mg}$ of algal cells using GeneJet RNA purification kit (Thermo Fisher Scientific, MA, USA) followed by synthesis of first-strand cDNA using RevertAid RT Reverse Transcription Kit (Thermo Fisher Scientific, MA, USA) according to the manufacturer's instruction. The level of gene expression was monitored by Real-time quantitative PCR performed with Universal SYBR Green Supermix (Bio-Rad, CA, USA) in Hard-Shell High-Profile 96-Well Semi-Skirted PCR Plates (Bio-Rad, CA, USA) using 50 ng cDNA as the template and primer pairs listed in Table 1.

Table 1

Primers used in the real time RT-PCR for quantifying the biosynthetic genes.

\begin{tabular}{|c|c|c|c|c|}
\hline Gene & Sequence $(5 \rrbracket-3 \rrbracket)$ & $\begin{array}{l}\mathrm{Tm} \\
\left({ }^{\circ} \mathrm{C}\right)\end{array}$ & Amplicon size (bp) & Reference \\
\hline \multirow[t]{2}{*}{$a c c D$} & (F) TTTGGTTTGTGCTTCTGGTG & 51.9 & 149 & [3] \\
\hline & (R) CACCACCAGTTGTTGGAGAA & & & \\
\hline \multirow[t]{2}{*}{$r b c L$} & (F) СTTTCCAAGGTCCTCCTCAC & 56.4 & 208 & [3] \\
\hline & (R) TCTCTCCAACGCATAAATGG & & & \\
\hline \multirow[t]{2}{*}{ KAS-1 } & (F) CCATGATTGGTCATTGCTTGGGAGC & 58 & 151 & [17] \\
\hline & (R) GCTCTTGCTTCATGTTTGGGACCAC & & & \\
\hline \multirow[t]{2}{*}{$\omega-6 F A D$} & (F) CTTCACCCACGAAGGCACAGGC & 58.8 & 129 & [17] \\
\hline & (R) CCTGCACACTGCTGGGAACG & & & \\
\hline \multirow[t]{2}{*}{$\omega-3 F A D$} & (F)CATGTTGAGAACGACGAGTCCTGGTAT & 59 & 162 & [17] \\
\hline & (R) GTCAAAGTGGGAGCCAGTCTTGC & & & \\
\hline \multirow[t]{2}{*}{ 18S rRNA } & (F) CCTGCGGCTTAATTTGACTCAACACG & 60 & 172 & [17] \\
\hline & (R) TAGCAGGCTGAGGTCACGTTCG & & & \\
\hline
\end{tabular}

All PCR reactions consists of $1 \mu \mathrm{L} 50 \mathrm{ng}$ cDNA template, $1.5 \mu \mathrm{L}$ of $10 \mathrm{mM}$ deoxyribonucleotide triphosphates, $0.4 \mu \mathrm{M}$ final concentration of each forward $(F)$ and reverse $(R)$ primers (Table 1), $10 \mu \mathrm{L} 2 \times$ iQ SYBR Green Supermix and nuclease-free water to final volume of $20 \mu \mathrm{L}$. RT-qPRC amplification protocol for targeted genes consists of initial denaturation for 3 min at $95^{\circ} \mathrm{C}$, followed by 40 cycles of three steps consisting of $15 \mathrm{~s}$ at $95^{\circ} \mathrm{C}, 20 \mathrm{~s}$ at appropriate annealing temperature and $30 \mathrm{~s}$ at $72^{\circ} \mathrm{C}$. The specificity of all PCR amplifications was verified with melting curve calculation at the completion of each run, set from $55^{\circ} \mathrm{C}$ to $95^{\circ} \mathrm{C}$ at $0.5^{\circ} \mathrm{C}$ increment. The gene expression levels were normalized by the expression level of 18S rRNA gene and data presented as fold increase or decrease of the target gene expression levels in the treated samples relative to the control sample $[23,24,3]$.

\subsection{Statistical analyses of experimental results}


The data were analysed by one-way ANOVA at $95 \%$ confidence limit $(\alpha=0.05)$. All statistical tests were performed using SPSS (v. 20, IBM). Unless otherwise stated, $p<0.05$ denotes a statistically significant difference. The values were expressed as the mean \pm standard deviation.

\section{Results And Discussion}

\subsection{Cell growth and biomass accumulation}

The effects of varying nutrient concentrations on the growth of Chlorella sp. T4 were investigated to ascertain suitable condition for biomass yield and high lipid productivity. Cultivation of microalgae under nutrient limiting condition has been reported to decrease the overall algal biomass, while inducing synthesis of neutral lipid suitable for biodiesel production [12]. In this study, nutrient stress conditions produced adverse effects on the proliferation of Chlorella sp. T4 cells (Fig. 1). As shown in Table 2, low specific growth rates $0.055 \pm 0.004 \mathrm{~h}^{-1}$ was observed when Chlorella sp. T4 was cultivated under $\mathrm{N}$ limiting medium, with short generation time of $0.079 \pm 0.005$ day $^{-1}$ compared to the control. High specific growth rate of $0.079 \pm 0.004 \mathrm{~h}^{-1}$ was observed under $\mathrm{N}$-replete medium which was not significantly higher than that the growth rate in the control medium. This is also reflected by similar growth pattern of Chlorella sp. T4 obtained in N-replete medium and control medium (Fig. 1a). It proves the importance of nitrogen as a macro nutrient required for protein synthesis and cell division in microalgae [11]. The observed growth patterns under $\mathrm{N}$ and P-limiting medium (Fig. 1) are consistent with those reported for other Chlorella strains $[17,14,25]$.

Table 2

Specific growth rate and doubling time of Chlorella sp. T4 cultivated in BG-11 medium with different N and $\mathrm{P}$ concentration.

\begin{tabular}{|c|c|c|}
\hline Nutrient treatment & Growth rate $\left(\mathrm{h}^{-1}\right)$ & Generation time $\left(\right.$ day $\left.^{-1}\right)$ \\
\hline Control & $0.076 \pm 0.014^{b}$ & $0.109 \pm 0.020^{\mathrm{ab}}$ \\
\hline $\mathrm{N}-0.75$ & $0.055 \pm 0.004^{c}$ & $0.079 \pm 0.005^{\mathrm{ab}}$ \\
\hline $\mathrm{N}-2.25$ & $0.079 \pm 0.004^{b}$ & $0.114 \pm 0.006^{b}$ \\
\hline P-0.02 & $0.050 \pm 0.011^{c}$ & $0.072 \pm 0.016^{c}$ \\
\hline P-0.06 & $0.098 \pm 0.014^{\mathrm{a}}$ & $0.147 \pm 0.020^{a}$ \\
\hline \multicolumn{3}{|c|}{$\begin{array}{l}\mathrm{N}-0.75, \mathrm{~N} \text {-limiting condition; } \mathrm{N}-2.25, \mathrm{~N} \text {-replete medium; } \mathrm{P}-0.02, \mathrm{P}-\text {-limiting condition and } \mathrm{P}-0.06, \mathrm{P}- \\
\text { replete medium; Control, } \mathrm{BG}-11 \text { containing } \mathrm{N}-1.5 \mathrm{~g} \mathrm{~L}-1+\mathrm{P}-0.04 \mathrm{~g} \mathrm{~L}-1 \\
\text { significant difference within the group according to one-way ANOVA at } p<0.05 \text {. Values show the } \\
\text { average of three replicates } \pm \text { SD. }\end{array}$} \\
\hline
\end{tabular}

The microalgae Chlorella sp. T4 showed tolerance to high N concentration as demonstrated by the growth curve similar to that obtained in the control medium. Similarly, higher specific growth rate was 
observed in medium with higher concentration of phosphorus. The specific growth rate $(0.050 \pm 0.011$ $\mathrm{h}^{-1}$ ) observed under P-limiting condition is about two-fold less compared to the value obtained in the Preplete medium $\left(0.098 \pm 0.014 \mathrm{~h}^{-1}\right)$. This was also corroborated by the growth patterns of the strain under P-limiting condition (Fig. 1b). P-replete medium produced higher generation time of $0.147 \pm 0.020$ day $^{-1}$, which is 1.35- and 2.04-fold higher than the generation times obtained in the control and P-limiting medium. Phosphorus is a constituent element of ATP, essential for photophosphorylation which has significant relevance to the cell growth and metabolism of microalgae. Photosynthetic microalgae require large amounts of proteins (mainly RuBisCO) which is synthesized by phosphorus-rich ribosome [26].

For all the experiments, biomass yield and productivity together with lipid content and productivity were calculated after 21 days cultivation period. Nitrogen replete medium (N-2.25) produced the highest biomass yield of $0.82 \pm 0.06 \mathrm{~g} \mathrm{~L}^{-1}$ which is $41.4 \%$ significantly $(p \otimes 0.05)$ higher than the biomass yield in the nitrogen deficiency $(\mathrm{N}-0.75)$ medium but not significantly different from that obtained in the control medium (Table 3). Similarly, 23.4\% significantly ( $p \otimes 0.05)$ higher biomass yield was obtained in P-replete (P-0.06) medium compared to the P-deficiency (P-0.02) medium. This is further correlated by the high biomass productivity $38.95 \pm 0.84 \mathrm{mg} \mathrm{L}^{-1} \mathrm{~d}^{-1}$ obtained under $\mathrm{N}$-replete medium $\left(38.95 \pm 0.84 \mathrm{mg} \mathrm{L}^{-1}\right.$ $\left.\mathrm{d}^{-1}\right)$ and P-replete medium (37.52 $\left.\pm 0.53 \mathrm{mg} \mathrm{L}^{-1} \mathrm{~d}^{-1}\right)$ due to high nutrient availability to utilize for cell division (Table 3). Reduction in nutrients concentration in media has been shown to slow down the metabolic activity and cell division in most microalgae, while triggering lipid accumulation [27]. It is therefore not surprising that a significantly 1.6 -fold and 1.2-fold increases in lipid productivity and lipid content were obtained in nitrogen limiting and phosphorus limiting medium, respectively, relative to the nutrient replete medium. 
Table 3

Cumulative lipid content (\% dcw) of Chlorella sp. T4 under different culture conditions

\begin{tabular}{|c|c|c|c|c|}
\hline Experiments & $\begin{array}{l}\text { Biomass } \\
\left(\mathrm{g} \mathrm{L}^{-1}\right)\end{array}$ & $\begin{array}{l}\text { Biomass productivity (mg } \\
\mathrm{L}^{-1} \mathrm{~d}^{-1} \text { ) }\end{array}$ & $\begin{array}{l}\text { Lipid } \\
\text { content } \\
\text { (\%dcw) }\end{array}$ & $\begin{array}{l}\text { Lipid productivity (mg } \\
\mathrm{L}^{-1} \mathrm{~d}^{-1} \text { ) }\end{array}$ \\
\hline Control & $\begin{array}{l}0.77 \pm \\
0.01^{\mathrm{ab}}\end{array}$ & $36.48 \pm 0.64^{a}$ & $\begin{array}{l}25.87 \pm \\
1.03^{c}\end{array}$ & $12.93 \pm 0.51^{b}$ \\
\hline $\mathrm{N}-0.75$ & $\begin{array}{l}0.58 \pm \\
0.03^{\mathrm{ab}}\end{array}$ & $27.58 \pm 1.23^{a}$ & $\begin{array}{l}31.07 \pm \\
0.53^{\mathrm{a}}\end{array}$ & $15.54 \pm 0.27^{a}$ \\
\hline $\mathrm{N}-2.25$ & $\begin{array}{l}0.82 \pm \\
0.06^{\mathrm{ab}}\end{array}$ & $38.99 \pm 0.85^{b}$ & $\begin{array}{l}19.99 \pm \\
0.01^{\mathrm{e}}\end{array}$ & $10 \pm 0.15^{b}$ \\
\hline P-0.02 & $\begin{array}{l}0.64 \pm \\
0.01^{\mathrm{b}}\end{array}$ & $30.28 \pm 0.68^{a}$ & $\begin{array}{l}28.33 \pm \\
1.35^{\mathrm{b}}\end{array}$ & $14.17 \pm 0.67^{b}$ \\
\hline P-0.0.6 & $\begin{array}{l}0.79 \pm \\
0.50^{\mathrm{a}}\end{array}$ & $37.52 \pm 0.53^{a}$ & $\begin{array}{l}23.80 \pm \\
0.26^{\mathrm{d}}\end{array}$ & $11.90 \pm 0.13^{b}$ \\
\hline
\end{tabular}

High biomass productivity by this microalgae strain under both nutrient rich and nutrient stressed conditions is very promising, since biomass productivity is one of the major traits that makes microalgae attractive feedstock for biofuel applications over plant-based feedstocks [28]. Similarly, [29] found that an increase in $\mathrm{N}$ concentration resulted high biomass yield of 1.56 and $1.78 \mathrm{~g} \mathrm{~L}^{-1}$ for Chlorella sorokiniana (PCH02) and Chlorella vulgaris (PCH05), respectively. The observed overall increase in biomass yield and biomass productivity in $\mathrm{N}$ and $\mathrm{P}$ rich medium of this strain may be due to luxurious uptake of phosphorus which gets deposited in the cell as polyphosphate involved in metabolic pathway and storage for further use during phosphorus starvation/ limitation [30]. Similarly, [25] reported an increase in biomass concentration of Chlorella minutissima MCC as the phosphate concentration increase from 0 to $3 \mathrm{mM}$.

\subsection{Chlorophyll content and physiological response of Chlorella sp. T4 under different nutrient conditions}

Chloroplast is an important unit component for most photosynthetic plants and algae. Hence, the chlorophyll content and the viability of the photosynthetic process are critical physiological indicator for monitoring microalgae adaptability to different culture conditions [14]. The chlorophyll a content was measured during the cultivation period as an indicator of the physiological response of Chlorella sp. T4 in different $\mathrm{N}$ and $\mathrm{P}$ conditions. An increase in chlorophyll a content was observed as the concentration of $\mathrm{N}$ and $\mathrm{P}$ increased in media. Highest chlorophyll a content (in mg/g dcw) of $27.11 \pm 0.01$ (Fig. 2a) and $26.50 \pm 0.67$ (Fig. 2b) was observed after 21 days in $\mathrm{N}$ and P-replete medium, respectively. A significantly 
( $p \otimes 0.05)$ decrease in chlorophyll a content by 1.2-fold and 1.4-fold under $\mathrm{N}$ and P-deficient conditions compare to the control, respectively, were recorded. It suggests that the decrease of $\mathrm{N}$ and $\mathrm{P}$ concentration in the medium results in lower cell chlorophyll accumulation due to scarcity of intracellular nitrogen and phosphorus pool to synthesize chlorophyll for further cell reproduction. Nitrogen and phosphorus are most important elements contributing to the growth of microalgae cell, it limitation significantly changes the biosynthesis of cell pigment [31]. The results clearly show the influence of nutrient limitation on the growth physiology of Chlorella sp. T4 as the growth rate and biomass yield also decreased under these conditions.

The widely used fluorescence parameter Fv/Fm, an index reflecting irradiance acclimation status [32] was investigated under nutrient deficient and replete medium. It represents the measure of photosystem II (PSII) quantum yield and could be used to evaluate the photo induced damage to protein complex [33]. The positive influence of $\mathrm{N}$ and $\mathrm{P}$ treatment conditions was observed on the growth of Chlorella sp. T4 (Fig. 2c, d). A significantly ( $p \otimes 0.05$ ) decrease in Fv/Fm by 1.21-fold and 1.12-fold was observed under $\mathrm{N}$ and P-limiting condition compared to the control, respectively. The decrease in Fv/Fm is an indicative of the photoinhibition of PSIl by Chlorella sp. T4. Microalgae tend to redirect their energy from photosynthetic process under nutrient starved conditions toward maximizing nutrient uptake upon nutrient addition, leading to a net decrease in the capacity of cells to dissipate energy photochemically [34]. Chlorella sp. T4 exhibited a steady decline in the photosynthetic parameter Fv/Fm under $\mathrm{N}$ and Preplete medium by 1.13-fold and 1.12-fold compared to the control, respectively. It has been shown that the Fv/Fm ratio in microalgae increase markedly when cultured under nutrient sufficient condition [3].

\subsection{Analysis of lipid content and composition}

Studies have shown that cultivation of microalgae under nutrients deficiency conditions stimulates lipid

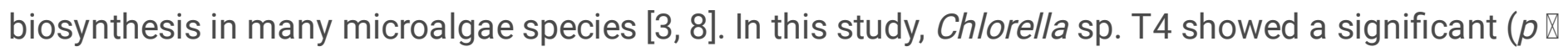
0.05 ) increase in total lipid yield under $N$ and P-limiting conditions, accounting for $31.07 \pm 0.53 \%$ and $28.33 \pm 1.35 \%$ of dry cell weight, respectively (Table 3). [35], cultivated $C$. zofingiensis under N and Pdeficient medium and reported higher lipid contents as compared to the nutrient sufficient medium which is similar to the present study. [3] also observed high lipid accumulation by Chlorella sorokiniana under $\mathrm{N}$ and P-deficient medium compare to the control medium. Contrary, [12] cultivated Chlorella sp. in medium containing different $\mathrm{N}$ concentration and observed an increase in lipid accumulation under $\mathrm{N}$-replete medium compare to $\mathrm{N}$-deficient conditions.

Lipid productivity is one of particular importance microalgal lipid production process as it considers both lipid content and biomass production rate. High lipid productivity of $15.54 \pm 0.7 \mathrm{mg} \mathrm{L}^{-1} \mathrm{~d}^{-1}$ was obtained under $\mathrm{N}$-limiting condition which was 1.37-fold higher than P-limiting condition after 21 days (Table 3). Nonetheless, nutrient limiting conditions repressed the growth of Chlorella sp. T4 and the overall productivity caused by nutrient deficiency was not offset by biomass loss. Similarly, [14] reported high lipid productivity of $47.05 \mathrm{mg} \mathrm{L}^{-1} \mathrm{~d}^{-1}$ under $\mathrm{N}$-deficiency in Chlorella pyrenoidosa after 5 days of cultivation. Also, [36] investigated the effects of phosphorus on lipid accumulation of Chlorella vulgaris 
and reported a lipid productivity of $19.40 \mathrm{mg} \mathrm{L}^{-1} \mathrm{~d}^{-1}$ in phosphorus deficient medium. Low lipid productivity was observed under N-replete medium $\left(10 \pm 0.15 \mathrm{mg} \mathrm{L}^{-1} \mathrm{~d}^{-1}\right)$ which was 2.32-fold lower than the control medium. These findings clearly show that high lipid productivity yield can be obtained by cultivating microalgae under nutrient deficiency conditions that has just enough nutrients to support the growth.

Microalgae biomass contains significant quantities of lipids in the form of triacylglycerol, which can be converted to biodiesel via transesterification process. This has attracted huge commercial interest of using microalgae as feedstock for biodiesel production [28]. The lipid composition of Chlorella sp. T4 varied according to the nutrient concentration of the growth medium (Table 4). Previous studies have also shown that the concentration of nitrogen and phosphorus in microalgae culture alter total fatty acid content and composition [17, 37]. Palmitic acid (C18:0), oleic acid (C18:1) and linoleic acid (C18:2) constitute the major fatty acids in algal oil. Fatty acids of this chain length are reported to be suitable for high quality biodiesel production [1]. Further analysis reveals that saturated fatty acid (SFA) ranged from $32-43.3 \%$, monounsaturated fatty acid (MUFA) ranged from $21.4-37.1 \%$, whereas polyunsaturated fatty acid (PUFAs) ranged from $27.1-37.3 \%$. Polyunsaturated fatty acids are important with nutritionally benefits for infant development and with estimated market value of over 11 billion US dollars [28].

Table 4

Fatty acids profile of biodiesel produced under different $\mathrm{N}$ and $\mathrm{P}$ condition after 21 days of cultivation.

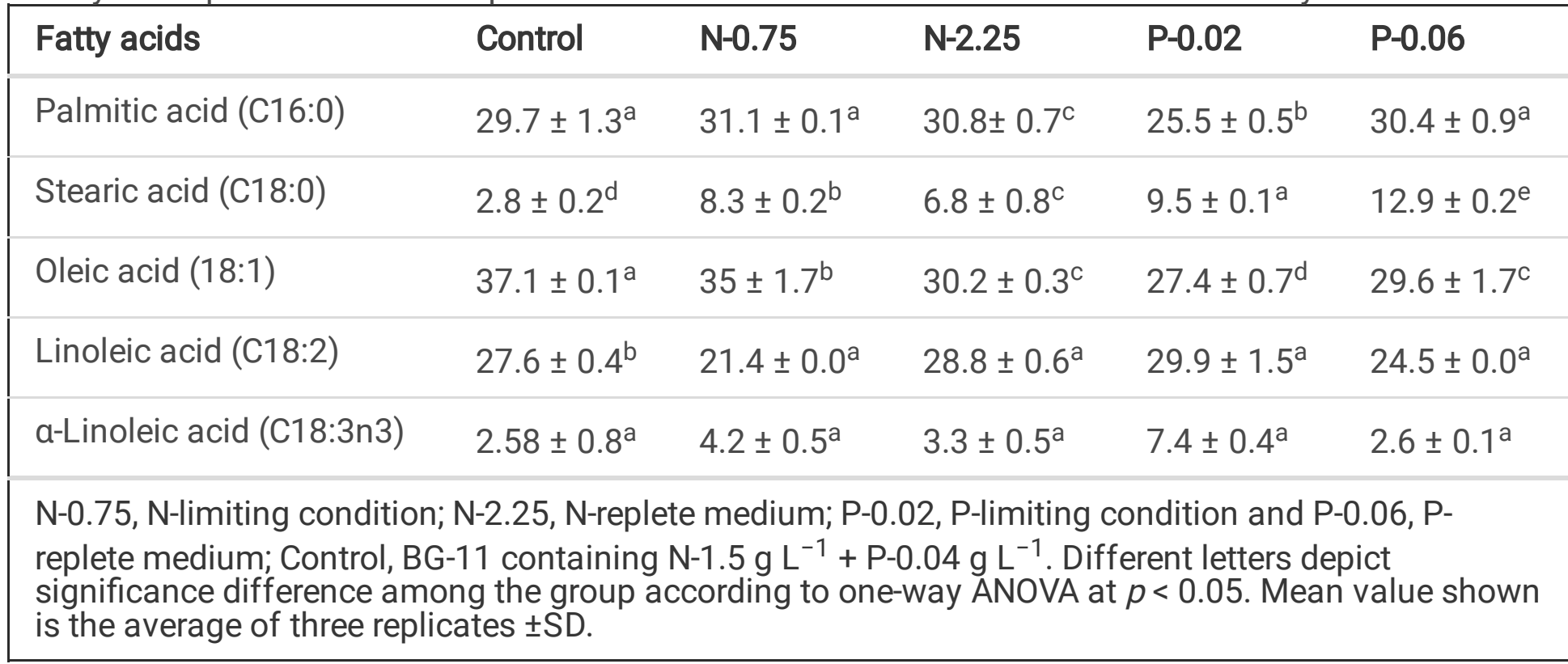

There was high level of saturated fatty acid observed under P-replete (49.9\%) medium, which is 1.3-fold higher than the control medium (Table 4). High level oleic acid (37.1 $\pm 0.1 \%$ ) was obtained in the control medium, but not significantly ( $p \otimes 0.05$ ) different from the level obtained in both the $\mathrm{N}$ and P-limiting medium. High content of oleic acid is beneficiary for excellent oxidative stability, increases biodiesel's flow properties and reduces it solidification temperature [38, 39]. Furthermore, high content of PUFAs was found in P-limiting condition which could cause decline of cetane number and oxidation stability, making 
biodiesel prone to oxidation-dependent degradation $[38,40]$. This finding was well with the results reported by [17] who reported that high accumulation of PUFAs was obtained under P-limiting condition.

The quality of microalgae biodiesel is measured by the important thermophysical properties of biodiesel and comparing those with the international standards such as ASTM D675 or EN14214 (Table 5).

Previous studies have demonstrated that fatty acid profile significantly affected the quality of biodiesel $[22,1]$. The oxidative stability of the biodiesel produced in this study ranged between 5.75 to $7.20 \mathrm{~h}$ which is favourable for biodiesel production due to saturated fatty acid [41]. This microalgae strain showed low cold filter plugging properties $\left(-2.75^{\circ} \mathrm{C}\right)$ under $\mathrm{N}$-limiting condition which is preferable for biodiesel production. This was caused by a good balance between the saturated fatty acid and monounsaturated fatty acid observed under the N-limiting condition. 
Table 5

Properties of Chlorella sp. T4 biodiesel cultivated in BG-11 medium with different N and P concentration compared to ASTM D6751 and EN 14214 specification [1].

\begin{tabular}{|c|c|c|c|c|c|c|c|}
\hline \multirow[t]{2}{*}{$\begin{array}{l}\text { Biodiesel properties } \\
\text { (Units) }\end{array}$} & \multicolumn{2}{|c|}{$\begin{array}{l}\text { Standard fuel } \\
\text { parameters }\end{array}$} & \multicolumn{5}{|c|}{ Transesterification } \\
\hline & $\begin{array}{l}\text { ASTM } \\
\text { D6751 }\end{array}$ & $\begin{array}{l}\text { EN } \\
14214\end{array}$ & Control & $\mathrm{N}-0.75$ & $\mathrm{~N}-2.25$ & $P-0.02$ & $P-0.06$ \\
\hline lodine value $\left(\mathrm{gl}_{2} / 100 \mathrm{~g}\right)$ & - & $\begin{array}{l}120 \\
(\max )\end{array}$ & 82 & 90.54 & 88.36 & 99.05 & 78.11 \\
\hline $\begin{array}{l}\text { Saponification value } \\
(\mathrm{mg} \mathrm{KOH})\end{array}$ & - & - & 205.42 & 211.12 & 204.67 & 210.51 & 204.62 \\
\hline Cetane number & $47(\min )$ & $\begin{array}{l}51.0 \\
(\mathrm{~min})\end{array}$ & 54.45 & 52.61 & 50.9 & 49.94 & 55.40 \\
\hline $\begin{array}{l}\text { Degree of unsaturation } \\
(\% \mathrm{wt})\end{array}$ & - & - & 86.50 & 97.60 & 94.40 & 102.00 & 83.80 \\
\hline $\begin{array}{l}\text { Long-chain saturation } \\
\text { factor (\% wt) }\end{array}$ & - & - & 7.26 & 4.37 & 6.48 & 7.63 & 9.49 \\
\hline $\begin{array}{l}\text { High heating value (MJ } \\
\left.\mathrm{kg}^{-1}\right)\end{array}$ & - & - & 39.56 & 39.51 & 39.38 & 40.60 & 39.45 \\
\hline $\begin{array}{l}\text { Cold filter plugging } \\
\text { properties }\left({ }^{\circ} \mathrm{C}\right)\end{array}$ & - & - & 6.33 & -2.75 & 3.88 & 7.49 & 13.34 \\
\hline $\begin{array}{l}\text { Kinematic viscosity } \\
\left(\mathrm{mm}^{2} \mathrm{~s}^{-1}\right)\end{array}$ & $1.9-6.0$ & $3.5-5.0$ & 1.35 & 1.33 & 1.33 & 1.36 & 1.35 \\
\hline Density $\left(\mathrm{g} \mathrm{cm}^{-3}\right)$ & - & $\begin{array}{l}0.86- \\
0.90\end{array}$ & 0.87 & 0.87 & 0.87 & 0.90 & 0.87 \\
\hline Oxidative stability (h) & $3(\min )$ & $\geq 6$ & 7.20 & 6.50 & 6.26 & 5.75 & 6.94 \\
\hline Linoleic acid (\%) & - & 12 & 27.6 & 21.4 & 28.8 & 29.9 & 24.5 \\
\hline $\begin{array}{l}\text { ASTM D-6751-American } \\
\mathrm{N}-0.75 \text {, N-limiting conditi } \\
\text { replete medium; Control, }\end{array}$ & $\begin{array}{l}\text { iety for } \mathrm{T} \\
\mathrm{N}-2.25, \mathrm{~N} \\
11 \text { contai }\end{array}$ & $\begin{array}{l}\text { g and I } \\
\text { ete mec } \\
\mathrm{N}-1.5\end{array}$ & $\begin{array}{l}\text { rials, } \\
; P-0.0 \\
+P-0\end{array}$ & $\begin{array}{l}\text { 14214- } \\
\text {-limitir } \\
\mathrm{g} \mathrm{L}^{-1} \text {. }\end{array}$ & $\begin{array}{l}\text { opean } \\
\text { onditio }\end{array}$ & $\begin{array}{l}\text { idard fo } \\
\text { nd P-0. }\end{array}$ & $\begin{array}{l}\text { iodiesel } \\
\text { P- }\end{array}$ \\
\hline
\end{tabular}

High saturated fatty acid content may reduce the cold filter plugging point properties of biodiesel because saturated fatty acid has higher melting points than unsaturated fatty acid [42]. Furthermore, kinematic viscosity $\left(\mathrm{mm}^{2} \mathrm{~s}^{-1}\right)$ produced by Chlorella sp. T4 under all $\mathrm{N}$ and $\mathrm{P}$ conditions was outside the range recommended by ASTM D675 and EN14214. This property may result into biodiesel produced with high viscosity affecting the fuel atomization and lead to deposits forming inside the engine, due to high PUFAs contain by microalgae compare to the other seed oils. Linoleic acid was above 12 recommended by EN14214 for all the conditions, an indication of poor oxidative stability with good cold flow properties 
[28]. In this study, the best biodiesel was produced under N-limiting condition, with high ignition quality, good oxidative stability, cetane number value and saponification value (Table 5).

\subsection{Effect of culture conditions on the expression of rbcL and accD genes of Chlorella sp. T4}

During photosynthesis, the RuBisCo enzyme is involved in carbon fixation process. A large subunit of this enzyme encoded by gene $r b c L$ which harbour binding site $[43,44]$. The present study evaluates the effect of nutrient conditions on the expression levels of some functional and fatty acids biosynthetic genes from Chlorella sp. T4. A significant ( $p \otimes 0.05$ ) decrease of 2.09-fold in the $r b c L$ gene expression was observed under $\mathrm{N}$-limiting condition after 21 days compare to the control (Fig. 3a). There was no significant difference in the expression level of $r b c L$ under N-replete compared to the control medium (Fig. 3a). Similarly, the $r b c L$ gene was significantly $(p \otimes 0.05)$ decreased by 1.59 -fold under P-limiting condition after 21 days compare to the control (Fig. 3b). Under nutrient stress, the cell protein synthesis and photosynthetic rates is affected as chlorophyll a is utilized as an intracellular nitrogen to support the growth of microalgae [45]. [14] cultivated Chlorella pyrenoidosa under $\mathrm{N}$ and P-deficient conditions and reported high expression of $r b c L$ gene in the nutrient condition which was two to five times higher than $\mathrm{N}$ deficient condition. [3] also reported $78 \%$ and $56 \%$ down regulation of $r b c L$ gene in $\mathrm{N}$ and $\mathrm{P}$ stress conditions on Chlorella sorokiniana, respectively. The decrease in the expression of $r b c L$ gene was also translated by low specific growth rate (Table 2) and decrease of maximum quantum efficiency of PSII (Fig. 2) under $\mathrm{N}$-limiting condition in this study. The expression of $r b c L$ gene was significantly $(p \otimes 0.05)$ increased by 1.12 -fold under P-limiting condition compared to the control medium just after 7-day incubation periods. (Fig. 3b). Microalgae utilizes phosphorus for the transfer and signal transduction during photosynthesis [46]. Microalgae under nutrient sufficient medium tend to require more fixed carbon cell construction, which then demand for more RuBisCO to sequester the $\mathrm{CO}_{2}$ in the air.

Acetyl-CoA carboxylase (ACCase) is regarded as rate-limiting enzyme for fatty acid synthesis and it has been overexpressed in different organism to enhance lipid production [6]. A study by [14] suggested a strong involvement of $a c c D$ in triggering lipid accumulation by the cell under nutrient deficient conditions. The present study evaluated the expression of heteromeric ACCase unit ( $\operatorname{acc} D$ gene) as a function of different $\mathrm{N}$ and $\mathrm{P}$ concentrations on lipid synthesis. A significant increase in the expression of acc $D$ gene was observed under nutrient limiting conditions during the cultivation period as compared to the cells grown in standard BG-11 medium (Fig. 3c \& d). In N-limiting condition, 3.11-fold increase of accD gene expression was observed after 21 days cultivation compared to the control (Fig. 3c). Likewise, a significant ( $p \otimes 0.05)$ 1.89-fold increase in the expression $a c c D$ gene by was observed under P-limiting condition after 21 days of cultivation compared to the control (Fig. 3d). Usually, lower photosynthetic rates cause NADH accumulation inhibiting enzyme citrate synthase so that the acetyl-CoA is blocked from entering TCA cycle. By increasing the acetyl-CoA concentration, ACCase is activated resulting in the enhancement of lipid content in microalgae [6]. This was evidently shown by an increase lipid yield by Chlorella sp. T4 under N and P-limiting conditions compare to the control medium (Table 3). During nutrient starvation, cell tends to synthesis lipids as a protective mechanism against stressful condition [47]. 
The expression of $a c c D$ gene under $\mathrm{N}$-replete medium was significantly lower compared to the control and $\mathrm{N}$-deficient medium, with 1.3-fold and 2.6-fold increase obtained, respectively at day 21 (Fig. 3c). Similarly, the expression of $a c c D$ gene under P-replete medium was significantly lower by 2.95 -fold compare to the control at day 21 (Fig. 3d). [3], cultivated Chlorella sorokiniana under $\mathrm{N}$ and P-limiting conditions along with metal stress. They recorded a 3.24-fold and 2.93-fold increase in the expression of $a c c D$ gene at the late log phase compared to the control medium (BG-11). Also, a significant correlation was found between the expression of $a c c D$ gene, growth rate, photosynthetic efficiency, and lipid accumulation. Based on the results obtained in the present study, the expression of $a c c D$ was observed to be higher under nutrient limiting medium. This was attributed by higher amount of lipid content under nutrient limiting medium despite lower biomass yield compared to $\mathrm{N}$-replete medium.

\subsection{Effect of culture conditions on the expression of KAS-1, $\omega-6$ and $\omega-3$ desaturase gene of Chlorella sp.} T4

Another key gene in the process for fatty acid biosynthesis is $K A S-1$ which is required for the addition of malonyl-CoA to elongate a 4-carbon fatty acid to 6-, 12- and 16 carbon fatty acid chains [18]. There was no significant difference in the expression level of $K A S-1$ gene under $\mathrm{N}$-deficiency and control medium

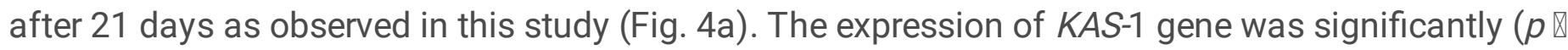
0.05 ) increased under $\mathrm{N}$ and P-replete medium by 1.12-fold (Fig. 4a) and 1.19-fold (Fig. 4d) after 21 days compare to the control, respectively. Usually, microalgae under normal growth condition consume ATP and NADPH produced by the cell though photosynthesis resulting in the formation of ADP and NADP ${ }^{+}$ that are being available again as acceptor molecules in photosynthesis [48]. This was translated by high biomass (Table 3 ) and abundance of saturated fatty acid (Table 4) observed in $\mathrm{N}$ and P-replete medium which can be attributed to the high expression level of KAS-1 gene under these conditions.

Aziz et al. [17] cultivated Chlorella strain KS-MAS under different $\mathrm{P}$ concentration and observed high expression of KAS1 gene under P-replete condition, which is about 3.7 and 4.3-fold higher than the control. They found a strong correlation between the expression of KAS1 and saturated fatty acid and biomass yield. The KAS-1 gene is known to catalyze the production of 18-carbon fatty acid from 16carbon fatty acid in which palmitic and steric acid are the final product of the fatty acid synthesis [49]. The expression of KAS1 gene significantly decreased under $\mathrm{N}$ and P-limiting conditions by 1.13-and 1.23-fold after 21 days compare to the control, respectively. This showed a strong correlation with the expression of $K A S-1$ gene with high biomass yield and saturated fatty acid accumulation by Chlorella sp. T4 under nutrient replete medium. Microalgae structural lipid is known to have a high content of polyunsaturated fatty acid. Under nutrient starvation, the carbon metabolism is affected and results in cell physiology regulation which increases the cellular demand for the synthesis of membrane phospholipids $[50,48]$.

Omega- 6 desaturase encoded by gene $\omega-6$ FAD catalyzes the conversion of oleic acid to linoleic acid. The expression level of $\omega-6$ FAD by Chlorella sp. T4 was affected by nutrient conditions. The expression of $\omega$-6 FAD was significantly ( $p \otimes 0.05$ ) increased under $\mathrm{N}$-limiting condition by 2.09 -fold at day 21 compared 
to the control (Fig. 4b). The increase in the expression of $\omega-6$ FAD under $\mathrm{N}$-limiting condition was corroborated by high level of linoleic acid ascertain under $\mathrm{N}$-limiting condition. Microalgae requires sufficient $\omega-6$ FAD gene expression to convert oleic acid substrate to linoleic acid [51]. The expression of $\omega-6$ FAD gene was significantly decreased in $\mathrm{N}$-replete medium by 1.83 -fold compare to the control medium (Fig. 4b). [52] reported high expression of $\omega-6$ FAD gene by Nannochloropsis oceanica under $\mathrm{N}$ starvation condition which led to an increase in linoleic acid content.

The expression of $\omega-6$ FAD was significantly increased under P-limiting condition by 1.97 -fold after 21 days compare to the control (Fig. 4e). The increase in the expression of $\omega-6$ FAD under P-limiting condition was corroborated by high level of oleic acid ascertain under $\mathrm{N}$ and P-limiting condition (Table 4). Omega- 6 desaturase is activated by the availability of oleic acid and a-linoleic acid. This suggests that the function of desaturase enzyme was satisfaction to the demand of membrane phospholipids for synthesis of PUFAs. The present study demonstrated that nutrient limiting conditions had a significant impact on the expression of $\omega-6 F A D$ and monounsaturated fatty acids.

Omega-3 desaturase encoded by gene $\omega-3 F A D$ plays important role in the conversion of linoleic acid to form trienoic fatty acid known as a-linoleic acid [53]. The expression of $\omega-3$ FAD gene was significantly ( $p$ $\otimes 0.05$ ) increased by 1.93 -fold and 1.65 -fold under $\mathrm{N}$ and P-limiting condition after 21 days compare to the control, respectively (Fig. 5c, f). The expression levels of $\omega-3$ FAD gene is strongly associated with the increase in a-linoleic acid level [51], which was corroborated by high levels of a-linoleic acids content that was ascertain under $\mathrm{N}$ and P-limiting conditions by Chlorella sp. T4 (Table 4). [54], reported overexpression of $\omega-3$ FAD gene by Chlorella vulgaris in transgenic tobacco plant which resulted to an increase in a-linoleic acids content. The expression of $\omega-3 F A D$ gene was significantly $(p \otimes 0.05)$ decreased under $\mathrm{N}$ and P-replete medium by 2-fold and 1.89-fold after 21 days compare to the control, respectively (Fig. 5c, f). Nevertheless, the accumulation of a-linoleic acid by Chlorella sp. T4 was relatively low to compare to other fatty acid. Omega-3 desaturase gene have been successfully overexpressed to increase the a-linoleic acids content $[52,51]$. Polyunsaturated fatty acid are major constituents of biological membrane which plays important role in maintaining the membrane fluidity and are essential for cell growth at low temperatures [53].

\section{Conclusion}

The cultivation of Chlorella so. T4 in nutrient replete medium has resulted in increase in the cell growth rate which was attributed by high chlorophyll content and quantum efficiency of photosystem II (Fv/Fm) value. The biomass was significantly decreased under nutrient-stress condition, as corroborated by significantly decrease in the expression of $r b c L$ gene. The correlation between the upregulation of $a c c D$ gene and enhanced lipid productivity by $\mathrm{N}$ and $\mathrm{P}$ limitation was observed indicating a clear impact of nutrient stress in Chlorella sp. T4. The level of KAS-1 gene was upregulated under nutrient replete medium, translated by high level of saturated fatty acid under non-nutrient stress conditions. Furthermore, an increase in the expression level of $\omega-6$ FAD and $\omega-3$ FAD genes under $\mathrm{N}$ and P-limiting medium was observed which corresponded to high levels of monounsaturated and polyunsaturated fatty 
acid. This provides a clue for future prospective metabolic engineering to make microalgal biodiesel economically viable. FAMEs produced under nutrient limiting condition were suitable for production of high-quality biodiesel with better oxidative stability and cold flow properties. Future research may focus on the overexpression of these key biosynthetic genes through metabolic engineering for higher yield of neutral lipid with good biodiesel properties.

\section{Abbreviations}

ASTM D-6751

American Society for Testing and Materials

DWC

dry cell weight

EN 14214

European standard for biodiesel

fatty acid methyl ester

FAME

fatty acid methyl ester

$\mathrm{Fv} / \mathrm{Fm}$

Low maximum quantum efficiency

GC-MS

gas chromatography mass spectrometry

$\mathrm{P}$

phosphorus

PUFA

polyunsaturated fatty acid

MUFA

monounsaturated fatty acid

$\mathrm{N}$

nitrogen

SFA

Saturated fatty acid.

\section{Declarations}

\section{Acknowledgments}

This work was supported the National Research Foundation (South Africa) and University of KwaZuluNatal for providing financial assistance.

Conflicts of interest and statement of informed consent, human/ animal rights 
Authors declare that they have no conflicts of interest. No conflicts, informed consent, human or animal and no financial or other interest that could influence the outcome of this research applicable.

\section{Author contributions}

All authors have contributed to this research and agree to authorship and submit this manuscript for its revision and publication. S.G., A.K and A.O conception and design of the paper. S.G and A.K analysis and interpretation of the data. S.G drafting of the manuscripts. A.K and A.O critical revision of the article for important intellectual content and final approval of the manuscripts.

\section{Funding}

National Research Foundation, South Africa (Grant No: 92803).

\section{References}

1. Sakthivel R, Ramesh K, Purnachandran R, Shameer PM (2018) A review on the properties, performance and emission aspects of the third generation biodiesels. Renew Sustain Energy Rev 82:2970-2992

2. Han F, Pei H, Hu W, Song M, Ma G, Pei R (2015) Optimization and lipid production enhancement of microalgae culture by efficiently changing the conditions along with the growth-state. Energy Conv Manag 90:315-322

3. Singh P, Kumari S, Guldhe A, Singh G, Bux F (2017) ACCase and rbcL gene expression as a function of nutrient and metal stress for enhancing lipid productivity in Chlorella sorokiniana. Energy Conv Manag 148:809-819

4. Singh P, Guldhe A, Kumari S, Rawat I, Bux F (2015) Investigation of combined effect of nitrogen, phosphorus and iron on lipid productivity of microalgae Ankistrodesmus falcatus KJ671624 using response surface methodology. Biochem Eng J 94:22-29

5. Chen Y, Tang X, Kapoore RV, Xu C, Vaidyanathan S (2015) Influence of nutrient status on the accumulation of biomass and lipid in Nannochloropsis salina and Dunaliella salina. Energy Conv Manag 106:61-72

6. Li YX, Zhao FJ, Yu DD (2015) Effect of nitrogen limitation on cell growth, lipid accumulation and gene expression in Chlorella sorokiniana.Brazilian Archives of Biology and Technology58 (3):462467

7. Mandotra S, Kumar P, Suseela M, Nayaka S, Ramteke P (2016) Evaluation of fatty acid profile and biodiesel properties of microalga Scenedesmus abundans under the influence of phosphorus, $\mathrm{pH}$ and light intensities. Bioresour Technol 201:222-229

8. Sukačová K, Búzová D, Trávníček P, Červený J, Vítězová M, Vítěz T (2019) Optimization of microalgal growth and cultivation parameters for increasing bioenergy potential: Case study using the oleaginous microalga Chlorella pyrenoidosa Chick (IPPAS C2). Algal Res 40:101519 
9. Ördög V, Stirk WA, Bálint P, Aremu AO, Okem A, Lovász C, Molnár Z, van Staden J (2016) Effect of temperature and nitrogen concentration on lipid productivity and fatty acid composition in three Chlorella strains. Algal Res 16:141-149

10. Negi S, Barry AN, Friedland N, Sudasinghe N, Subramanian S, Pieris S, Holguin FO, Dungan B, Schaub T, Sayre R (2016) Impact of nitrogen limitation on biomass, photosynthesis, and lipid accumulation in Chlorella sorokiniana. J Appl Phycol 28(2):803-812

11. Singh P, Kumari S, Guldhe A, Misra R, Rawat I, Bux F (2016) Trends and novel strategies for enhancing lipid accumulation and quality in microalgae. Renew Sustain Energy Rev 55:1-16

12. Kiran B, Pathak K, Kumar R, Deshmukh D, Rani N (2016) Influence of varying nitrogen levels on lipid accumulation in Chlorella sp. Int J Environ Sci Technol 13(7):1823-1832

13. Vo T, Mai T, Vu H, Van D, Dao H, Tran P, Nguyen N, Nguyen P, Nguyen NC (2017) Effect of osmotic stress and nutrient starvation on the growth, carotenoid and lipid accumulation in Dunaliella salina A9. A9, Research in Plant Sciences. 5:1-8. doi:1

14. Fan J, Cui Y, Wan M, Wang W, Li Y (2014) Lipid accumulation and biosynthesis genes response of the oleaginous Chlorella pyrenoidosaunder three nutrition stressors.Biotechnology for biofuels7 (1):17

15. Gumbi S, Majeke B, Olaniran A, Mutanda T (2017) Isolation, identification and high-throughput screening of neutral lipid producing indigenous microalgae from South African aquatic habitats. Appl Biochem Biotechnol 182(1):382-399

16. Fan J, Cui Y, Wan M, Wang W, Li Y (2014) Lipid accumulation and biosynthesis genes response of the oleaginous Chlorella pyrenoidosa under three nutrition stressors. Biotechnol Biofuels 7(1):1-14

17. Aziz A, Siti M, Osman TsC, Sow HL (2016) Phosphate-induced changes in fatty acid biosynthesis in Chlorella sp. KS-MA2 strain

18. Kainou K, Kamisaka Y, Kimura $K$, Uemura $H(2006)$ Isolation of $\Delta 12$ and $\omega 3$-fatty acid desaturase genes from the yeast Kluyveromyces lactis and their heterologous expression to produce linoleic and a-linolenic acids in Saccharomyces cerevisiae. Yeast 23(8):605-612

19. Wang M, Chen H, Gu Z, Zhang H, Chen W, Chen YQ (2013) w3 Fatty acid desaturases from microorganisms: structure, function, evolution, and biotechnological use. Appl Microbiol Biotechnol 97(24):10255-10262

20. Porra R, Thompson W, Kriedemann P (1989) Determination of accurate extinction coefficients and simultaneous equations for assaying chlorophylls $a$ and b extracted with four different solvents: verification of the concentration of chlorophyll standards by atomic absorption spectroscopy. Biochimica et Biophysica Acta (BBA)-Bioenergetics 975(3):384-394

21. Gupta PL, Choi H-J, Pawar RR, Jung SP, Lee S-M (2016) Enhanced biomass production through optimization of carbon source and utilization of wastewater as a nutrient source. J Environ Manage 184:585-595

22. Odjadjare EC, Mutanda T, Chen Y-F, Olaniran AO (2018) Evaluation of pre-chlorinated wastewater effluent for microalgal cultivation and biodiesel production. Water 10(8):977 
23. Livak KJ, Schmittgen TD (2001) Analysis of relative gene expression data using real-time quantitative PCR and the $2-\Delta \Delta C T$ method. methods 25 (4):402-408. doi:https://doi.org/10.1006/meth.2001.1262

24. Schmittgen TD, Livak KJ (2008) Analyzing real-time PCR data by the comparative C T method.Nature protocols3 (6):1101

25. Chakraborty S, Mohanty D, Ghosh S, Das D (2016) Improvement of lipid content of Chlorella minutissima MCC 5 for biodiesel production. J Biosci Bioeng 122(3):294-300

26. Ågren GI (2004) The C: N: P stoichiometry of autotrophs-theory and observations. Ecol Lett 7(3):185-191

27. Liu T, Li Y, Liu F, Wang C (2016) The enhanced lipid accumulation in oleaginous microalga by the potential continuous nitrogen-limitation (CNL) strategy. Bioresour Technol 203:150-159

28. Odjadjare EC, Mutanda T, Olaniran AO (2017) Potential biotechnological application of microalgae: a critical review. Crit Rev Biotechnol 37(1):37-52

29. Paranjape K, Leite GB, Hallenbeck PC (2016) Strain variation in microalgal lipid production during mixotrophic growth with glycerol. Bioresour Technol 204:80-88

30. Powell N, Shilton AN, Pratt S, Chisti Y (2008) Factors influencing luxury uptake of phosphorus by microalgae in waste stabilization ponds. Environ Sci Technol 42(16):5958-5962

31. Li Y, Horsman M, Wang B, Wu N, Lan CQ (2008) Effects of nitrogen sources on cell growth and lipid accumulation of green alga Neochloris oleoabundans. Appl Microbiol Biotechnol 81(4):629-636

32. White S, Anandraj A, Bux F (2011) PAM fluorometry as a tool to assess microalgal nutrient stress and monitor cellular neutral lipids. Bioresour Technol 102(2):1675-1682

33. Cosgrove J, Borowitzka M (2006) Applying pulse amplitude modulation (PAM) fluorometry to microalgae suspensions: stirring potentially impacts fluorescence. Photosynth Res 88(3):343-350

34. Liang C, Zhai Y, Xu D, Ye N, Zhang X, Wang Y, Zhang W, Yu J (2015) Correlation between lipid and carotenoid synthesis and photosynthetic capacity in Haematococcus pluvialis grown under high light and nitrogen deprivation stress.Grasas y Aceites66 (2):077

35. Feng P, Deng Z, Hu Z, Fan L (2011) Lipid accumulation and growth of Chlorella zofingiensis in flat plate photobioreactors outdoors. Bioresour Technol 102(22):10577-10584

36. Chu F-F, Chu P-N, Cai P-J, Li W-W, Lam PK, Zeng RJ (2013) Phosphorus plays an important role in enhancing biodiesel productivity of Chlorella vulgaris under nitrogen deficiency. Bioresour Technol 134:341-346

37. Jouhet J, Lupette J, Clerc O, Magneschi L, Bedhomme M, Collin S, Roy S, Maréchal E, Rebeille F (2017) LC-MS/MS versus TLC plus GC methods: consistency of glycerolipid and fatty acid profiles in microalgae and higher plant cells and effect of a nitrogen starvation. PLoS ONE 12(8):e0182423

38. Hoekman SK, Broch A, Robbins C, Ceniceros E, Natarajan M (2012) Review of biodiesel composition, properties, and specifications. Renew Sustain Energy Rev 16(1):143-169 
39. Knothe G (2009) Improving biodiesel fuel properties by modifying fatty ester composition. Energy Environ Sci 2(7):759-766

40. Monirul IM, Masjuki HH, Kalam MA, Zulkifli NWM, Rashedul HK, Rashed MM, Imdadul HK, Mosarof $\mathrm{MH}$ (2015) A comprehensive review on biodiesel cold flow properties and oxidation stability along with their improvement processes. RSC Adv 5(105):86631-86655

41. Karpagam R, Preeti R, Ashokkumar B, Varalakshmi P (2015) Enhancement of lipid production and fatty acid profiling in Chlamydomonas reinhardtii, CC1010 for biodiesel production. Ecotoxicol Environ Saf 121:253-257

42. Francisco EC, Neves DB, Jacob-Lopes E, Franco TT (2010) Microalgae as feedstock for biodiesel production: carbon dioxide sequestration, lipid production and biofuel quality. Journal of Chemical Technology \& Biotechnology 85(3):395-403

43. Andersson I, Backlund A (2008) Structure and function of Rubisco. Plant Physiol Biochem 46(3):275-291

44. Msanne J, Xu D, Konda AR, Casas-Mollano JA, Awada T, Cahoon EB, Cerutti H (2012) Metabolic and gene expression changes triggered by nitrogen deprivation in the photoautotrophically grown microalgae Chlamydomonas reinhardtii and Coccomyxa sp. C-169 Phytochemistry 75:50-59

45. Vo T, Mai T, Vu H, Van D, Dao H, Tran P, Nguyen N, Nguyễn P, Nguyen N (2017) Effect of Osmotic Stress and Nutrient Starvation on the Growth, Carotenoid and Lipid Accumulation in Dunaliella salina A9. Research in Plant Sciences 5:1-8

46. Adams C, Godfrey V, Wahlen B, Seefeldt L, Bugbee B (2013) Understanding precision nitrogen stress to optimize the growth and lipid content tradeoff in oleaginous green microalgae. Bioresour Technol 131:188-194

47. Courchesne NM, Parisien A, Wang B, Lan CQ (2009) Enhancement of lipid production using biochemical, genetic and transcription factor engineering approaches. J Biotechnol 141(1-2):31-41

48. Sharma KK, Schuhmann H, Schenk PM (2012) High lipid induction in microalgae for biodiesel production. Energies 5(5):1532-1553

49. Zhang Y, Wang H, Zhang J, Hu Y, Zhang L, Wu X, Su X, Li T, Zou X, Liang B (2016) The cytochrome b5 reductase HPO-19 is required for biosynthesis of polyunsaturated fatty acids in Caenorhabditis elegans. Biochimica et Biophysica Acta (BBA)-Molecular and Cell Biology of Lipids 1861 (4):310-319

50. Romano S, Schulz-Vogt HN, González JM, Bondarev V (2015) Phosphate limitation induces drastic physiological changes, virulence-related gene expression, and secondary metabolite production in Pseudovibrio sp. strain FO-BEG1. Appl Environ Microbiol 81(10):3518-3528

51. Norashikin MN, Loh SH, Aziz A, San Cha T (2018) Metabolic engineering of fatty acid biosynthesis in Chlorella vulgaris using an endogenous omega-3 fatty acid desaturase gene with its promoter. Algal Res 31:262-275

52. Kaye Y, Grundman O, Leu S, Zarka A, Zorin B, Didi-Cohen S, Khozin-Goldberg I, Boussiba S (2015) Metabolic engineering toward enhanced LC-PUFA biosynthesis in Nannochloropsis oceanica: 
Overexpression of endogenous $\Delta 12$ desaturase driven by stress-inducible promoter leads to enhanced deposition of polyunsaturated fatty acids in TAG. Algal Res 11:387-398

53. Lau CC, Loh SH, Aziz A, San Cha T (2017) Effects of disrupted omega-3 desaturase gene construct on fatty acid composition and expression of four fatty acid biosynthetic genes in transgenic Chlorella vulgaris. Algal Res 26:143-152

54. Chlorella genes for $\Delta 12$ and $\omega-3$ Fatty acid desaturase (FAD): Isolation of $\Delta 12$ and $\omega-3$ fad cDNA Clones,... Bioscience, biotechnology, and biochemistry 66 (6):13141327.doi:https://doi.org/10.1271/bbb.66.1314

\section{Figures}

(a)

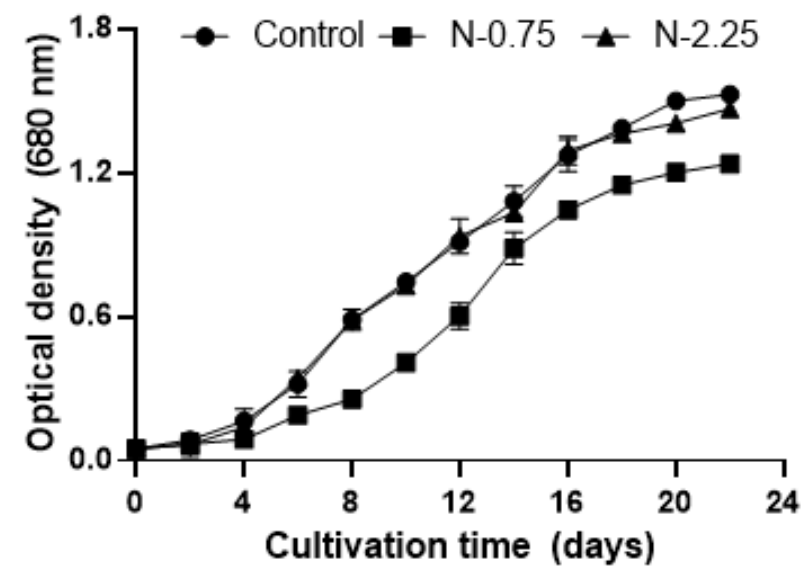

(b)

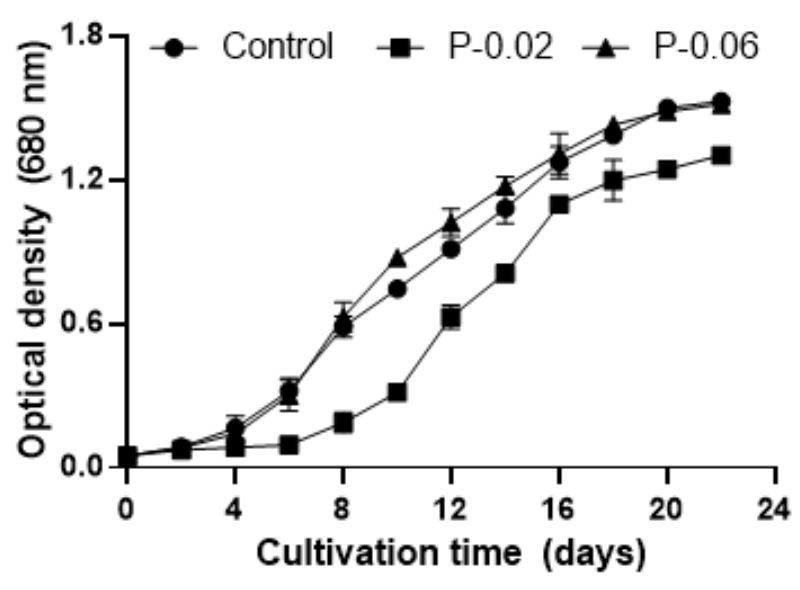

Figure 1

Growth curve of Chlorella sp. T4 under different nutrient conditions (a) N-treatment (g L-1), (b) Ptreatment ( $\mathrm{g} \mathrm{L}-1)$. N-0.75, N-limiting condition; N-2.25, N-replete medium; P-0.02, P-limiting condition and P-0.06, P-replete medium; Control, BG-11 containing N-1.5 g L-1 + P-0.04 g L-1. Values show the average of three replicates $\pm S D$. 
(a)

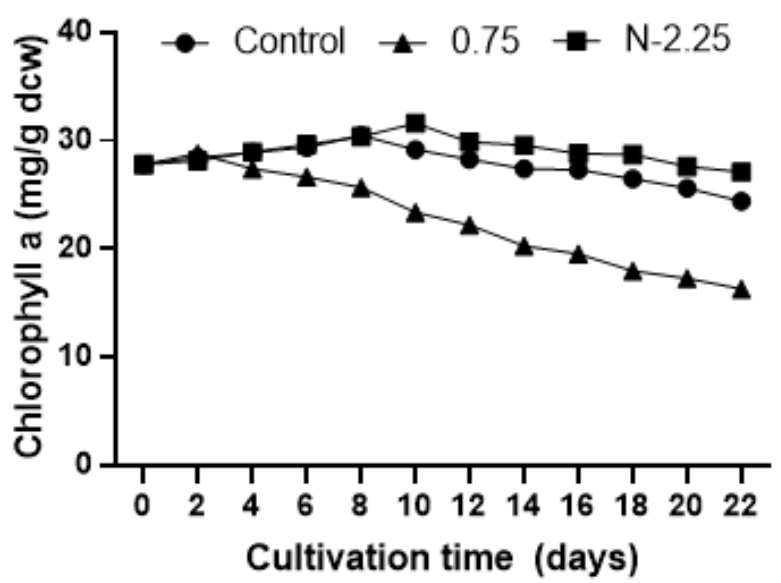

(c)

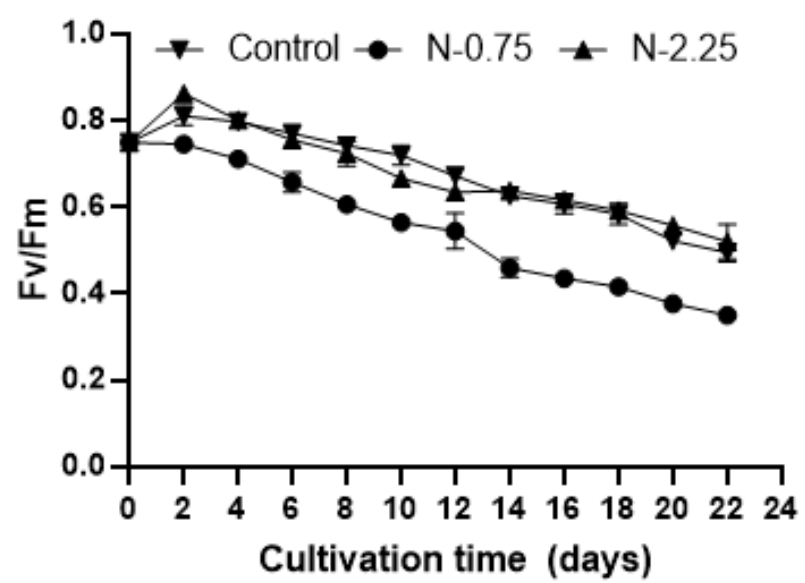

(b)

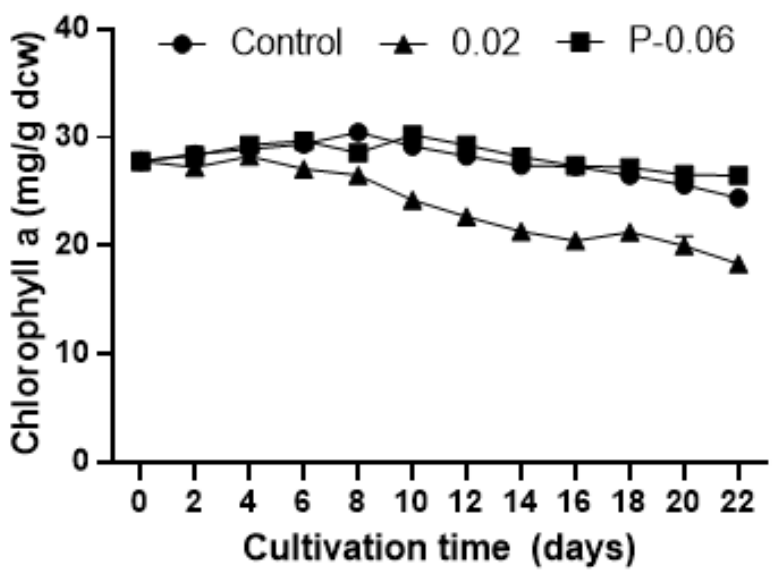

(d)

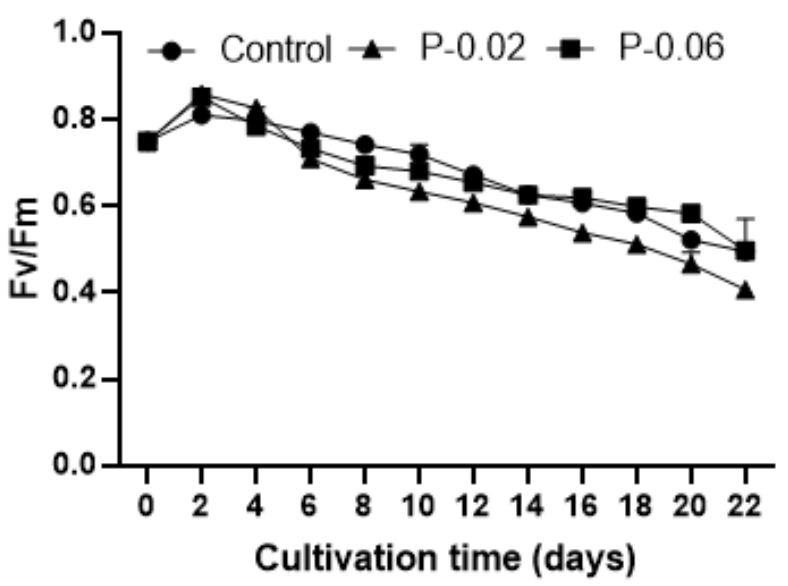

Figure 2

Photosynthetic activity of Chlorella sp. T4 under different nutrient conditions (a) Chlorophyll a under N treatment, (b) Chlorophyll a under $\mathrm{P}$ treatment, (c) Fv/Fm value under $\mathrm{N}$ treatment and (d) Fv/Fm value under $\mathrm{P}$ treatment. $\mathrm{N}-0.75, \mathrm{~N}$-limiting condition; $\mathrm{N}-2.25, \mathrm{~N}$-replete medium; $\mathrm{P}-0.02, \mathrm{P}-$-limiting condition and P-0.06, P-replete medium; Control, BG-11 containing N-1.5 g L-1 + P-0.04 g L-1. Values show the average of three replicates $\pm S D$. 
(a)

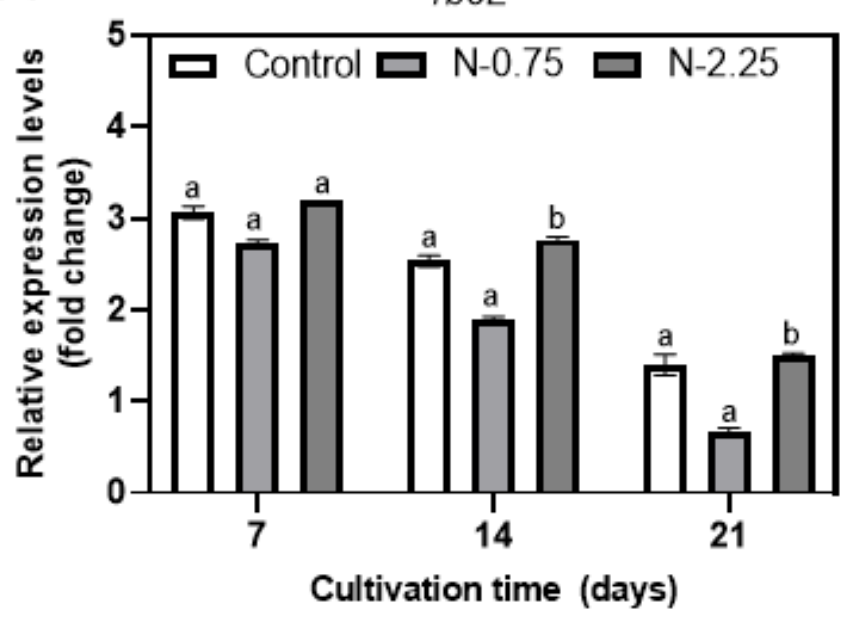

(c)

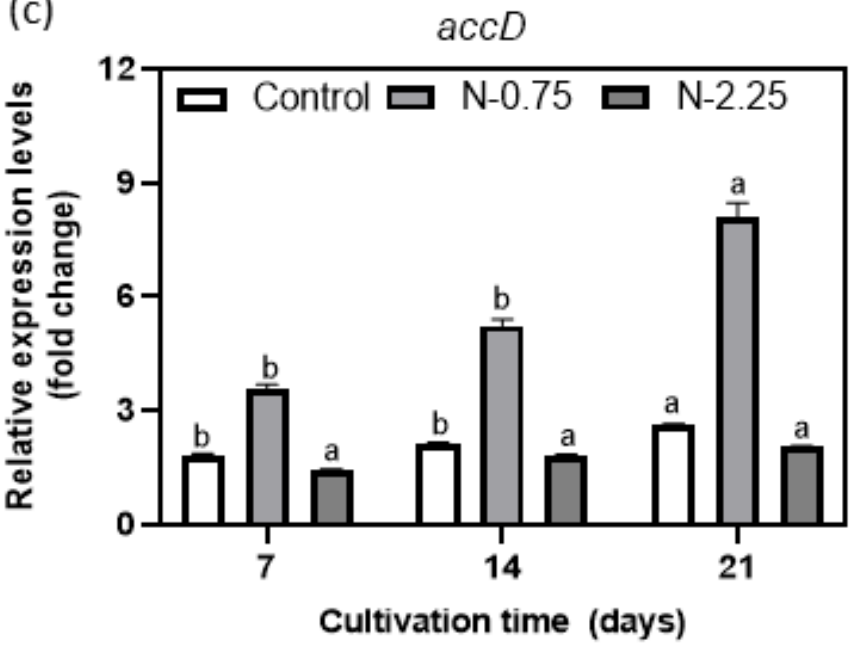

(b)
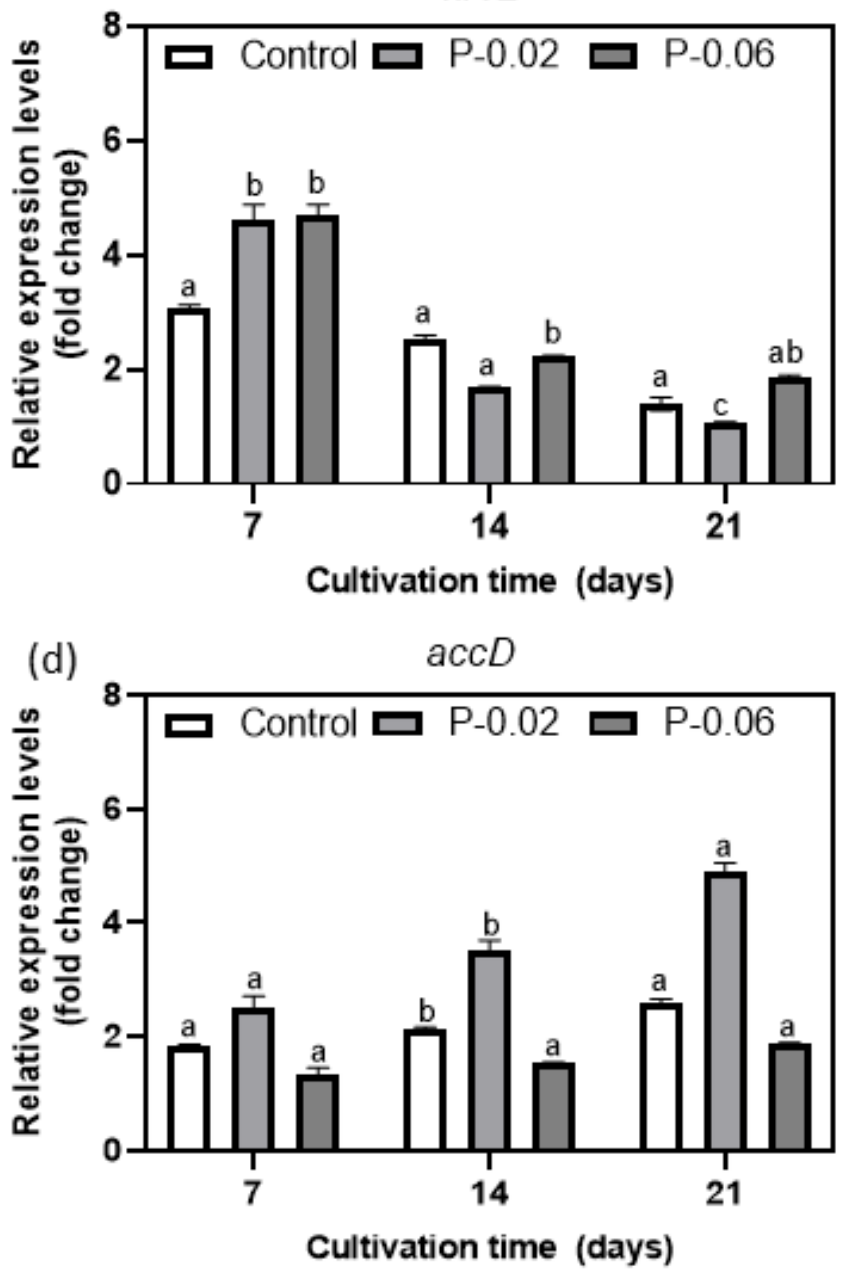

Figure 3

Mean fold of relative gene expression of rbcL gene of Chlorella sp. T4 cultured in different $\mathrm{N}$ and $\mathrm{P}$ concentration. Fold change was relative to the control treatment. (a) rbcL- N-treatment, (b) rbcL- Ptreatment, (c) accD- N-treatment and (d) accD-P treatment. N-0.75, N-limiting condition; N-2.25, N-replete medium; P-0.02, P-limiting condition and P-0.06, P-replete medium; Control, BG-11 containing N-1.5 g L-1 $+\mathrm{P}-0.04 \mathrm{~g} \mathrm{~L}-1$. Different letters depict significance difference among the gene expression according to one-way ANOVA at $p<0.05$. Values show the average of three replicates $\pm S D$. 

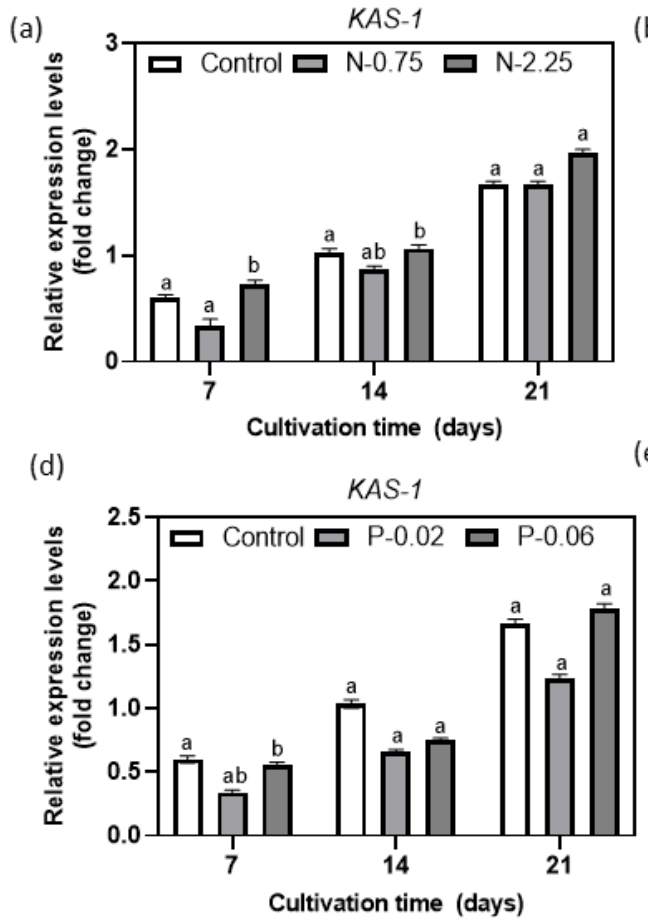

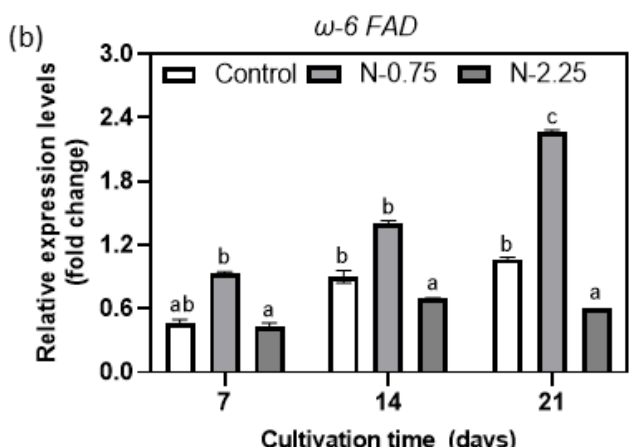

(e)

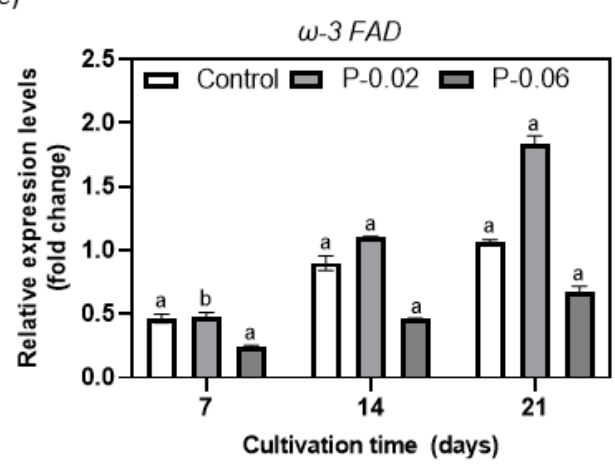

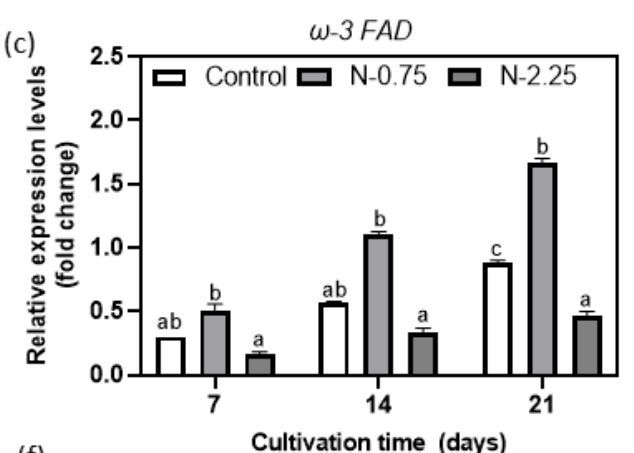

(f)

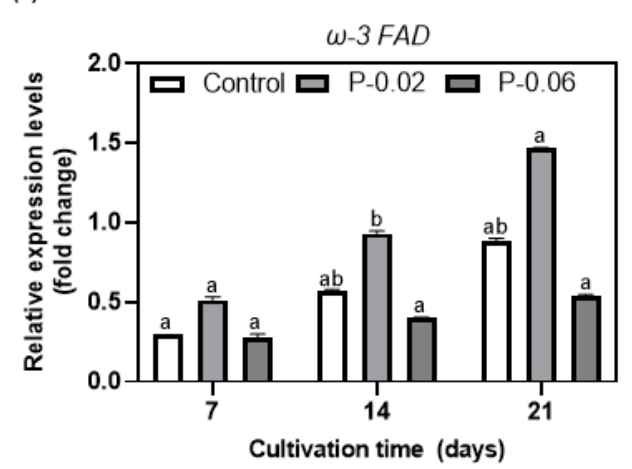

\section{Figure 4}

Mean fold of relative gene expression of rbcL gene of Chlorella sp. T4 cultured in different $\mathrm{N}$ and $\mathrm{P}$ concentration. Fold change was relative to the control treatment. (a) KAS-1-N-treatment, (b) w-6 FAD- Ptreatment, (c) w-3 FAD- N-treatment and (d) KAS-1- P-treatment, (E) w-6 FAD- P-treatment and (f) $\omega-3$ FADP-treatment. N-0.75, N-limiting condition; N-2.25, N-replete medium; P-0.02, P-limiting condition and P0.06, P-replete medium; Control, BG-11 containing N-1.5 g L-1 + P-0.04 g L-1. Different letters depict significance difference among the gene expression according to one-way ANOVA at $p<0.05$. Values show the average of three replicates $\pm S D$. 